\title{
RESONANSI BRAGG PADA ALIRAN AIR AKIBAT DINDING SINUSOIDAL DI SEKITAR MUARA SUNGAI
}

\author{
Viska Noviantri \\ Jurusan Matematika dan Statistik, Fakultas Sains dan Teknologi, Universitas Bina Nusantara \\ Jln. K.H. Syahdan No. 9, Palmerah, Jakarta Barat 11480 \\ viskanoviantri@binu.ac.id
}

\begin{abstract}
Basically, the water wave (wave) that passes through uneven base will have a solution to the wave transmission and reflection. It has been found also that the sinusoidal basis with certain conditions can cause the Bragg resonance. This paper will show that the wave propagation through the wall of river water can also cause sinusoidal Bragg resonance. Bragg resonance will occur if the sinusoidal wall of the wave number twice the number of incoming waves. Both analytically and numerically, the river wall with amplitude sinusoidal small amplitude can be reduced significantly due to the Bragg resonance. More specifically, the situation would be different if we consider the river mouth in the form of a hard wall of the dam. The existence of the hard wall of the dam at the mouth of the river it can cause the amplitude of the waves crashing against the transmission of large dams increased many-fold.
\end{abstract}

Keywords: Bragg resonance, sinusoidal wall, multi-scale asymptotic expansion

\begin{abstract}
ABSTRAK
Pada dasarnya, gelombang air (gelombang datang) yang melewati dasar tak rata akan mengalami pemecahan menjadi gelombang transmisi dan refleksi. Telah diketahui juga bahwa dasar sinusoidal dengan kondisi tertentu dapat menyebabkan terjadinya resonansi Bragg. Paper ini akan menunjukkan bahwa perambatan gelombang air yang melewati dinding sungai sinusoidal juga dapat menimbulkan resonansi Bragg. Resonansi Bragg akan terjadi jika bilangan gelombang dinding sinusoidal sebesar dua kali lipat bilangan gelombang datang. Baik secara analitik maupun numerik, dinding sungai sinusoidal dengan amplitudo yang kecil dapat mereduksi amplitudo gelombang datang secara signifikan akibat adanya resonansi Bragg. Lebih khusus lagi, situasi akan berbeda jika kita tinjau muara sungai yang berupa bendungan hard wall. Adanya bendungan hard wall di muara sungai ternyata dapat menyebabkan amplitudo gelombang transmisi yang menabrak bendungan bertambah besar sekian kali lipat.
\end{abstract}

Kata kunci: resonansi Bragg, dinding sinusoidal, ekspansi asimtotik multi skala 


\section{PENDAHULUAN}

Gelombang air laut dengan amplitudo yang besar dapat menimbulkan kerusakan pantai dan untuk mengurangi kerugian akibat terjangan gelombang tersebut adalah dengan membuat tembok laut. Pembuatan tembok laut sebagai pemecah gelombang tentu saja membutuhkan biaya yang tidak sedikit. Pemikiran berlanjut pada pemecah gelombang alami, yaitu memanfaatkan bentuk dasar laut tak rata. Pada prinsipnya setiap gelombang yang melewati dasar dengan kedalaman berbeda akan terpecah menjadi dua bagian, yaitu gelombang transmisi dan refleksi (Hirose dan Karl, 1985).

Dalam kasus dasar sinusoidal, perpecahan gelombang ini terjadi berulang-ulang tak berhingga kali. Bentuk dasar laut tak rata yang berupa sinusoidal melalui pendekatan linier sudah pernah dikaji terlebih dahulu oleh Viska (2007). Kajian tak linier dari masalah ini dapat diperoleh dari Yu Jie dan C.C Mei (2000). Dapat ditunjukkan bahwa hasil dari pendekatan linier ini serupa dengan kajian tak liniernya, yaitu bila panjang gelombang permukaan dua kali lipat panjang gelombang dasar sinusoidal, akan muncul gejala resonansi Bragg: Amplitudo dasar sinusoidal yang relatif kecil akan memecah gelombang datang menjadi gelombang refleksi dengan amplitudo yang relatif besar dan gelombang transmisi dengan amplitudo yang relatif kecil.

Berdasarkan hasil penelitian terdahulu, penulis tertarik untuk membahas kajian linier dari perambatan gelombang air yang melewati dasar rata tetapi dindingnya berbentuk sinusoidal. Apakah hal yang sama akan terjadi? Berbeda dengan penelitian terdahulu, pengkajian pengaruh dinding sinusoidal bukan ditinjau melalui amplitudo gelombang simpangan air melainkan melalui amplitudo dari fungsi kecepatan potensial partikel fluida di permukaan air yang selanjutnya disebut amplitudo gelombang saja. Hasil pengkajian memberikan hasil yang serupa, yaitu dinding sinusoidal dapat menyebabkan terjadinya resonansi Bragg jika bilangan gelombang dinding sinusoidal sebesar dua kali lipat bilangan gelombang datang.

Pengkajian ini melibatkan aspek fisika dalam menganalisa arti fisis dari persamaanpersamaan yang digunakan. Untuk menyederhanakan pembahasan, maka pengkajian ini hanya akan membahas gelombang datang yang berupa gelombang monokromatik. Penulis menggunakan persamaan yang diturunkan oleh Kirby (Philip dan Liu, 1986) untuk memperoleh solusi gelombang pada dinding sinusoidal. Solusi ini diselesaikan dengan menggunakan metode ekspansi asimtotik multi skala. Besarnya amplitudo gelombang transmisi yang menuju bendungan dapat dilihat melalui penyelesaian baik secara analitik maupun numerik.

Perambatan air akan menjadi menarik jika kita membahas aliran sungai yang sudah dekat dengan muara sungai atau bendungan. Besarnya amplitudo gelombang transmisi yang menabrak dinding bendungan juga dipengaruhi oleh karakteristik dinding bendungan. Karakteristik bendungan yang dimaksud adalah kemampuan bendungan dalam menyerap atau memantulkan gelombang datang. Paduan antara besarnya amplitudo dinding sinusoidal dengan karakteristik bendungan yang berbeda akan memberikan efek yang berbeda pula pada besarnya amplitudo gelombang transmisi yang menabrak bendungan. Paper ini hanya akan mengkaji kasus ekstrim dari karakteristik muara sungai, yaitu muara sungai yang dapat menyerap dan memantulkan gelombang secara sempurna.

\section{METODE PENELITIAN}

Metode yang digunakan dalam penelitian ini adalah metode deskriptif melalui studi literatur. Namun hal ini ditunjang dengan memberikan hasil penelitian berupa solusi analitik dan numerik. Kesesuaian antara solusi analitik dan numerik dapat memberikan penjelasan yang lebih spesifik mengenai hasil penelitian yang diperoleh. 
Solusi analitik dan numerik yang diperoleh merupakan hasil simulasi dari data-data yang digunakan. Data yang digunakan dalam penelitian ini diperoleh dari percobaan laboratorium yang dilakukan oleh seseorang bernama Heatershaw pada tahun 1982 dan digunakan oleh peneliti sebelumnya (C.C. Mei, 2004). Data ini merupakan data percobaan mengenai perambatan gelombang air di atas dasar berbentuk sinusoidal. Data ini meliputi berbagai kombinasi nilai perbandingan antara amplitudo dasar laut sinusoidal dengan kedalaman air ketika dasar rata, panjang dasar sinusoidal, bilangan gelombang datang dan bilangan gelombang dasar sinusoidal, dan amplitudo gelombang permukaan air yang datang. Walaupun data-data tersebut mengenai dasar sinusoidal, namun penulis menerapkannya untuk hal yang serupa yaitu dinding sinusoidal.

\section{HASIL DAN PEMBAHASAN}

\section{Persamaan Gelombang untuk Dinding Sinusoidal}
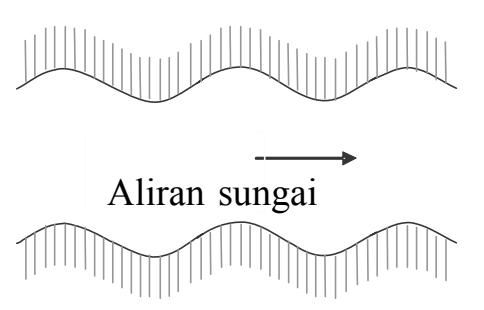

Tipe 1
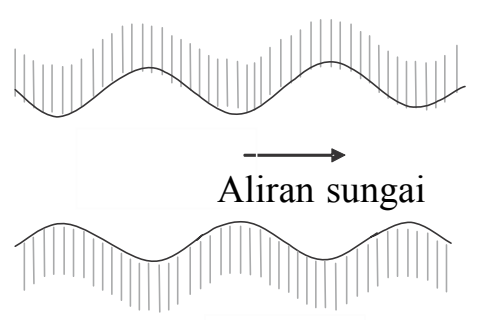

Tipe 2

Gambar 1 Dua Tipe Dinding Sungai Sinusoidal Dilihat dari Atas

Dinding sungai berbentuk sinusoidal adalah bentuk dinding tak rata yang berupa fungsi sinus atau cosinus. Dinding sungai berbentuk sinusoidal ini biasanya terdiri dari beberapa lengkungan. Lengkungan ini sama bentuknya seperti gundukan pada dasar laut sinusoidal. Terdapat dua tipe bentuk dinding sungai sinusoidal. Kedua tipe bentuk dinding sinusoidal dapat dilihat pada Gambar 1 . berikut:

Perhatikan Gambar 2. Misalkan bentuk dinding sungai sinusoidal diberikan oleh fungsi

$$
\begin{gathered}
a_{1}(x)=a(1+\varepsilon G \cos K x), \\
a_{2}(x)=-a(1+\varepsilon G \cos K x) .
\end{gathered}
$$

dengan $a$ setengah kali lebar sungai dalam keadaan dinding sungai rata, $a \varepsilon G$ menyatakan amplitudo lengkungan dinding sinusoidal, dan $K$ menyatakan bilangan gelombang dinding sinusoidal. Parameter $\varepsilon G$ tak berdimensi yang menyatakan perbandingan antara amplitudo simpangan dinding sinusoidal dengan setengah lebar sungai ketika dindingnya rata, $a$. Lebar sungai dinyatakan oleh:

$$
b(x)=2 a(1+\varepsilon G \cos K x) .
$$


y

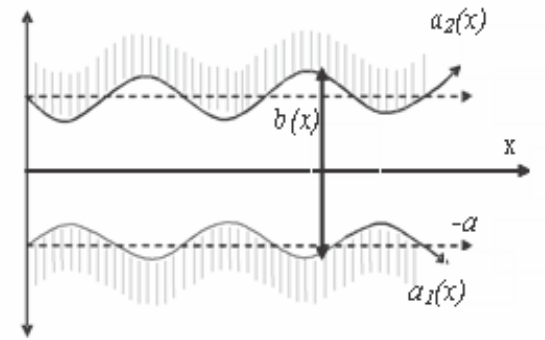

Gambar 2 Skema Dinding Sinusoidal Dilihat dari Atas

Dengan memisalkan dinding sungai berupa batas kaku, maka syarat batas yang berlaku sepanjang sungai adalah:

$$
\begin{aligned}
& \frac{\partial \phi\left(x, a_{1}\right)}{\partial x} \frac{\partial\left(a_{1}\right)}{\partial x}-\frac{\partial \phi\left(x, a_{1}\right)}{\partial y}=0, \\
& \frac{\partial \phi\left(x, a_{2}\right)}{\partial x} \frac{\partial\left(a_{2}\right)}{\partial x}-\frac{\partial \phi\left(x, a_{2}\right)}{\partial y}=0 .
\end{aligned}
$$

Kirby (Philip dan Liu, 1986) menunjukkan bahwa untuk masalah ini berlaku persamaan berikut:

$$
\frac{\partial^{2} \phi}{\partial t^{2}}-\nabla\left[\left(c^{2}+\frac{g \widetilde{h}}{\cosh ^{2} k h_{0}}\right) \nabla \phi\right]=0,
$$

dengan $\tilde{\boldsymbol{h}}$ adalah fungsi satu peubah yang merepresentasikan topografi dasar sungai. Asumsikan dasar sungai rata, $\tilde{\boldsymbol{h}}=\mathbf{0}$. Kemudian integralkan (6) dari $y=a_{\mathbf{1}}(x)$ sampai $y=a_{2}(x)$ dan terapkan formula Leibniz serta gunakan syarat batas pada (4) dan (5) sehingga diperoleh persamaan gelombang satu dimensi pada dasar sungai rata sebagai berikut:

$$
\frac{\partial^{2} \phi(x, t)}{\partial t^{2}}-\frac{c^{2}}{b(x)} \frac{\partial}{\partial x}\left[b(x) \frac{\partial \phi}{\partial x}\right]=0 .
$$

Perhatikan (7). Untuk dinding sinusoidal tipe 1 (lihat Gambar 1), diketahui bahwa $b(x)$ adalah konstan sehingga persamaan (7) dapat disederhanakan menjadi persamaan gelombang satu dimensi yang memiliki solusi d'Alembert (Strauss, 1992). Oleh karena itu, dinding sinusoidal tipe 1 tidak akan dibahas pada makalah ini.

Perhatikan bahwa untuk dinding sinusoidal tipe 2, $b(x)$ diberikan oleh (3) sehingga persamaan gelombang satu dimensi pada dasar sungai rata yang memiliki dinding sinusoidal dapat dituliskan secara eksplisit sebagai berikut:

$$
\frac{\partial^{2} \phi}{\partial t^{2}}=\frac{c^{2}}{(1+\varepsilon G \cos K x)} \frac{\partial}{\partial x}\left[(1+\varepsilon G \cos K x) \frac{\partial \phi}{\partial x}\right]
$$

dengan $\emptyset$ menyatakan kecepatan potensial partikel fluida yang ada di permukaan sungai.

Kemudian, terapkan metode ekspansi asimtotik multi skala (Holmes, 1995) untuk memperoleh solusi persamaan (8). Mula - mula akan diperkenalkan variabel 'cepat' dan 'lambat', yang dapat dituliskan secara berturut-turut sebagai berikut: 


$$
\begin{array}{rrr}
\widehat{x}=x & \text { dan } & \bar{x}=\varepsilon x . \\
\widehat{t}=t & \text { dan } & \bar{t}=\varepsilon t,
\end{array}
$$

sehingga turunan parsialnya menjadi:

$$
\frac{\partial}{\partial x} \rightarrow \frac{\partial}{\partial \widehat{x}}+\varepsilon \frac{\partial}{\partial \bar{x}} \quad \frac{\partial}{\partial t} \rightarrow \frac{\partial}{\partial \widehat{t}}+\varepsilon \frac{\partial}{\partial \bar{t}}
$$

Ekspansi asimtotik untuk diberikan oleh:

$$
\phi(\widehat{x}, \bar{x} ; \hat{t}, \bar{t})=\phi_{0}(\widehat{x}, \bar{x} ; \hat{t}, \bar{t})+\varepsilon \phi_{1}(\widehat{x}, \bar{x} ; \hat{t}, \bar{t})+\varepsilon^{2} \phi_{2}(\widehat{x}, \bar{x} ; \hat{t}, \bar{t})+\ldots
$$

Substitusikan (9), (10) dan (11) ke dalam (8) sehingga diperoleh suku-suku yang berorde $O$ (1) sebagai berikut:

$$
\frac{\partial^{2} \eta_{0}}{\partial t^{2}}-c^{2} \frac{\partial^{2} \eta_{0}}{\partial x^{2}}=0
$$

yang memiliki solusi sebagai berikut:

$$
\phi_{0}=\frac{A(\bar{x}, \bar{t})}{2} e^{i k x-i \omega t}+c . c+\frac{B(\bar{x}, \bar{t})}{2} e^{-i k x-i \omega t}+c . c .
$$

Perhatikan bahwa $\frac{A(\bar{x}, \bar{t})}{2}$ dan $\frac{E(\bar{x}, \bar{t})}{2}$ secara berturut-turut merupakan envelope bagi komponen $\emptyset$ yang menjalar ke kanan dan ke kiri.

Untuk $K=2 k$, maka persamaan yang memiliki $O(\varepsilon)$ adalah

$$
\begin{aligned}
\frac{\partial^{2} \phi_{1}}{\partial t^{2}}-c^{2} \frac{\partial^{2} \phi_{1}}{\partial x^{2}}= & c^{2}\left[\frac{\partial A}{\partial \bar{x}}(-i k) e^{i k x-i \omega t}+c . c+\frac{\partial B}{\partial \bar{x}}(-i k) e^{-i k x-i \omega t}+c .\right] \\
& -\left[\frac{\partial A}{\partial \bar{t}}(-i \omega) e^{i k x-i \omega t}+c . c+\frac{\partial B}{\partial \bar{t}}(-i \omega) e^{-i k x-i \omega t}+c . c\right] \\
& -\frac{G k c^{2}}{2}\left(k A e^{3 i k x-i \omega t}+c . c-k A e^{-i k x-i \omega t}+c . c\right. \\
& \left.-k B e^{i k x-i \omega t}+c . c+k B e^{-3 i k x-i \omega t}+c . c\right) .
\end{aligned}
$$

Untuk menghindari resonansi yang tidak terbatas dan untuk menjamin adanya solusi bagi $\emptyset_{1}$, maka koefisien-koefisien $\exp ( \pm(k x-\omega t))$ dan $\exp ( \pm(k x-\omega t))$ pada ruas kanan (15) harus dibuat nol sehingga diperoleh sebagai berikut:

$$
\begin{aligned}
& c \frac{\partial A(\bar{x}, \bar{t})}{\partial \bar{x}}+\frac{\partial A(\bar{x}, \bar{t})}{\partial \bar{t}}=\frac{i k c G}{2} B(\bar{x}, \bar{t}), \\
& \frac{\partial B(\bar{x}, \bar{t})}{\partial \bar{t}}-c \frac{\partial B(\bar{x}, \bar{t})}{\partial \bar{x}}=\frac{i k c G}{2} A(\bar{x}, \bar{t}) .
\end{aligned}
$$

Seperti pada dasar sinusoidal, pada kasus dinding sinusoidal juga dapat diperoleh persamaan Klein-Gordon sebagai berikut: 


$$
\frac{\partial^{2} A(\bar{x}, \bar{t})}{\partial \bar{t}^{2}}-c^{2} \frac{\partial^{2} A(\bar{x}, \bar{t})}{\partial \bar{x}^{2}}+\left(\Omega_{0}\right)^{2} \alpha(\bar{x}, \bar{t})=0
$$

dengan

$$
\Omega_{0} \equiv \frac{k c G}{2}=\frac{\omega G}{2}
$$

yang memiliki dimensi (satuan) frekuensi.

Bayangkan suatu gelombang monokromatik dengan amplitudo $A_{0}$ dan bilangan gelombang $k$ datang dari sebelah kiri daerah sinusoidal dengan bilangan gelombang $K$ di mana $K$ dan $k$ memenuhi hubungan $K=2 k$. Misalkan daerah dinding sinusoidal terletak pada $0<\mathrm{x}<\mathrm{L}$, maka di sebelah kiri dasar sinusoidal, yaitu ketika $\mathrm{x}<0$, gelombang yang merambat ke kanan dan ke kiri tidak saling berinteraksi. Pada daerah ini, gelombang $A$ dan $B$ bergerak mengikuti persamaan transport. Pada awal pengamatan $\bar{t}=0$, gelombang monokromatik diasumsikan baru mencapai $\bar{x}=0$ sehingga pada daerah dinding sinusoidal belum ada gelombang sama sekali. Dengan demikian, diperoleh syarat awal $A(\bar{x}, 0)=0$ dan $B(\bar{x}, 0)=0$. Pada batas kiri $\bar{x}=0$, gelombang yang merambat ke kanan hanya berasal dari gelombang datang sehingga diperoleh syarat batas kiri $A(0, \bar{t})=A_{0}$.

Saat gelombang melewati dasar sinusoidal yang panjangnya $L$, yaitu pada daerah $0<\bar{x}<$ $\bar{L}$, maka akan terjadi resonansi Bragg. Interaksi antara gelombang transmisi dan refleksi ini digambarkan melalui sistem persamaan (16) dan (17). Asumsikan bahwa di sebelah kanan daerah sinusoidal terdapat muara sungai yang dapat menyerap semua gelombang sehingga gelombang akan terus merambat ke kanan tanpa ada gangguan sehingga pada daerah ini tidak ada gelombang refleksi ke kiri. Berdasarkan asumsi ini, maka diperoleh syarat batas kanan $B(\bar{L}, \bar{t})=0$.

Pada domain $0<\bar{x}<\bar{L}$, dimisalkan solusinya berbentuk:

$$
\begin{aligned}
& A(\bar{x}, \bar{t})=A_{0} T(\bar{x}), \\
& B(\bar{x}, \bar{t})=A_{0} R(\bar{x}),
\end{aligned}
$$

dengan $T(\bar{x})$ menyatakan koefisien transmisi dan $R(\bar{x})$ menyatakan koefisien refleksi. Substitusikan kedua solusi tersebut ke dalam persamaan Klein Gordon (18) untuk memperoleh persamaan diferensial dalam fungsi $T(\bar{x})$ dan $R(\bar{x})$. Penyelesaian persamaan diferensial dengan menggunakan syarat awal dan ssyarat batas yang ada akan memberikan solusi analitik berupa koefisien transmisi dan refleksi untuk kasus resonansi sempurna. Koefisien transmisi dan refleksi secara berturut-turut adalah sebagai berikut:

$$
T(\bar{x})=\frac{\cosh \frac{k G(\bar{L}-\bar{x})}{2}}{\cosh \frac{k G \bar{L}}{2}} \quad \text { dan } \quad R(\bar{x})=\frac{i \sinh \frac{k G(\bar{L}-\bar{x})}{2}}{\cosh \frac{k G \bar{L}}{2}}
$$




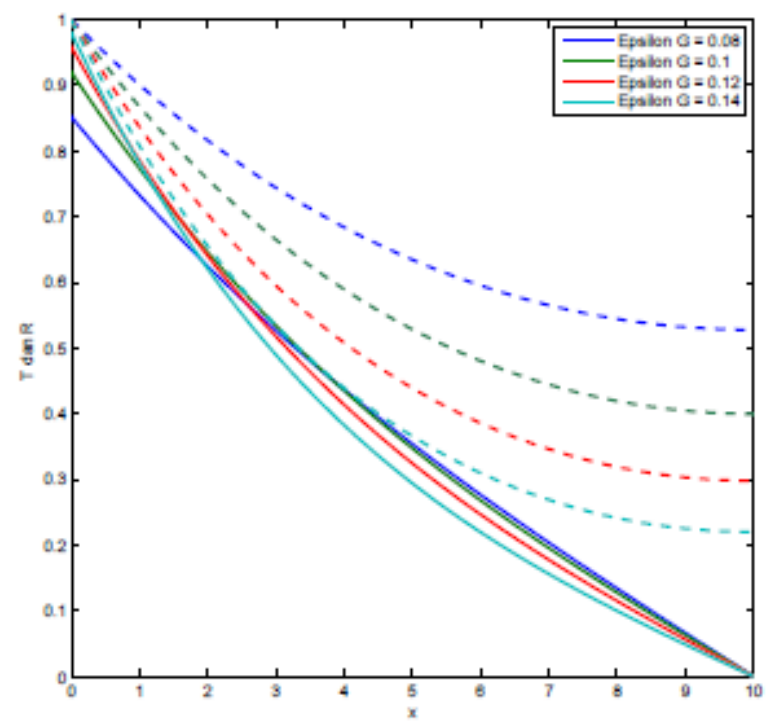

Gambar 3 Grafik $R(x)$ dan $T(x)$ pada Dinding Sinusoidal untuk $L=10, K=2 k=2 \pi$.

Gambar 3 menunjukkan hasil simulasi secara analitik dan numerik untuk beberapa nilai perbandingan antara amplitudo dinding sinusoidal dengan lebar sungai $(\varepsilon G)$. Kurva putus-putus dan kurva mulus secara berturut-turut merepresentasikan $T$ dan $R$. Kurva $T$ dan $R$ tersebut diplot untuk $\varepsilon G=0.08,0.1,0.12$, dan 0.14 . Nilai $T(10)$ yang lebih besar adalah untuk $\varepsilon G$ yang lebih kecil, sedangkan nilai $R(0)$ yang lebih besar adalah untuk $\varepsilon G$ yang lebih besar.

\section{Pengaruh Muara Sungai pada Resonansi}

Jika kita menganalogikan muara sungai seperti pantai yang memiliki kemampuan untuk menyerap atau memantulkan gelombang datang, maka kita akan menemui berbagai karakteristik muara sungai. Muara sungai yang terdiri dari pasir atau tanah memiliki kemampuan menyerap gelombang yang cukup besar (daya pantulnya kecil), sedangkan muara sungai yang terdiri dari batubatu keras (hard wall) dapat memantulkan gelombang secara sempurna. Selain material penyusun muara sungai, bentuk muara juga mempengaruhi besarnya pemantulan gelombang. Pada kenyataannya, tidak ada pantai yang memantulkan atau menyerap gelombang secara sempurna. Di sini, akan dibahas dua tipe muara, yaitu muara yang dapat menyerap dan memantulkan gelombang secara sempurna.

Jika $A$ dan $B$ berturut-turut menyatakan amplitudo yang bergerak ke kanan dan ke kiri, $|R|$ menyatakan proporsi amplitudo gelombang yang dipantulkan, dan $\theta$ adalah beda fase antara gelombang datang dan gelombang pantul, maka seperti halnya pantai, kemampuan muara sungai dalam menyerap atau memantulkan gelombang direpresentasikan oleh persamaan berikut:

$$
\frac{B(L, t)}{A(L, t)}=|R| e^{i \theta}
$$

Melalui analisis lebih lanjut, maka akan diperoleh syarat batas kanan yang menunjukkan hubungan antara $A$ dan $B$ untuk beberapa jenis muara (lihat Tabel 1). 
Tabel 1 Syarat Batas Kanan di $x=L$ untuk Beberapa Karakteristik Pantai

\begin{tabular}{ccc}
\hline Jenis Muara Sungai & Beda Fasa Antara A dan B $(\boldsymbol{\theta})$ & Syarat Batas Kanan \\
\hline Menyerap sempurna & & $B(L, t)=0$ \\
Memantulkan sempurna & 0 & $B(L, t)=A(L, t)$ \\
& $\Pi$ & $B(L, t)=-A(L, t)$ \\
\hline
\end{tabular}

Untuk melihat perambatan gelombang di daerah dinding sinusoidal yang merambat ke kanan (A) dan ke kiri (B), persamaan (16) dan (17) didiskritisasi dengan metode beda hingga, yaitu secara berturut-turut menggunakan FTBS dan FTFS.

Selain melihat perambatan gelombang transmisi dan refleksi, kita juga perlu meninjau transfer energi antara gelombang transmisi dan refleksi. Melalui transfer energi, kita dapat mengetahui berapa lama waktu yang dibutuhkan oleh gelombang sampai tidak ada lagi interaksi antara gelombang transmisi dan refleksi. Interaksi antara gelombang transmisi dan refleksi dinyatakan oleh hubungan berikut:

$$
\frac{1}{2}\left(U-c_{0}^{2}\right) \partial_{x}\left[\left|A\left(x, t_{0}\right)\right|^{2}-\left|B\left(x, t_{0}\right)\right|^{2}\right]=0, \quad \forall x \in[0, L],
$$

di mana $\left(|A|^{2}-|B|^{2}\right) / 2$ menyatakan fluks energi.

Transfer energi antara $A$ dan $B$ akan terus terjadi selama $\left(\left|A\left(x, t_{0}\right)\right|^{2}-\left|B\left(x, t_{0}\right)\right|^{2}\right) / 2$ masih berubah- ubah terhadap posisi $x$. Dengan kata lain, transfer energi berhenti ketika $\left(\left|A\left(x, t_{0}\right)\right|^{2}-\mid\right.$ $\left.\left.B\left(x, t_{0}\right)\right|^{2}\right) / 2=$ konstan.

\section{Kasus 1 Muara Sungai Menyerap Gelombang dengan Sempurna}

Jika muara sungai berupa bendungan yang dapat menyerap gelombang, maka perambatan gelombang yang melalui dinding sinusoidal dapat dilihat pada Gambar 4. Misalkan gelombang datang dengan amplitudo $A_{0}=1$. Pada saat $t=0.1$, gelombang datang belum melewati semua bagian dasar sinusoidal sehingga ada bagian dari $A, B$, dan fluks energi yang bernilai nol, yaitu pada daerah yang belum dilewati gelombang. Hal serupa juga masih terlihat saat $t=0.5$. Walaupun demikian, pemecahan gelombang sudah terjadi sejak gelombang datang memasuki dasar sinusoidal. Hal ini ditandai dengan adanya bagian amlitudo gelombang refleksi yang tidak nol, yaitu pada suatu daerah di mana gelombang transmisi sudah mencapai daerah tersebut. Pada saat $t=1$, gelombang datang sudah melewati semua bagian dasar sinusoidal sehingga tidak ada lagi $A, B$, dan fluks energi yang bernilai nol.

Sebelum gelombang mencapai $x=10$, amplitudo gelombang $A$ cenderung menurun seiring dengan perambatannya ke kanan, sedangkan amplitudo gelombang $B$ cenderung meningkat seiring dengan perambatannya ke kiri. Hal ini disebabkan karena adanya transfer energi dari $A$ ke $B$. Transfer energi ini terus terjadi sampai $t=5$. Transfer energi terjadi karena adanya pengaruh dinding sinusoidal. Saat $t \geq 5$, tidak ada lagi transfer energi antara $A$ dan $B$ sehingga nilai $A$ dan $B$ tidak berubah-ubah lagi terhadap posisi. Pada akhirnya diperoleh bahwa amplitude gelombang datang terreduksi hingga $\pm 53 \%$ saja yang ditransmisikan. Hal ini diakibatkan oleh dinding sinusoidal dengan amplitudo sebesar 0.08 dari lebar sungai $(\varepsilon G=0.08)$. 

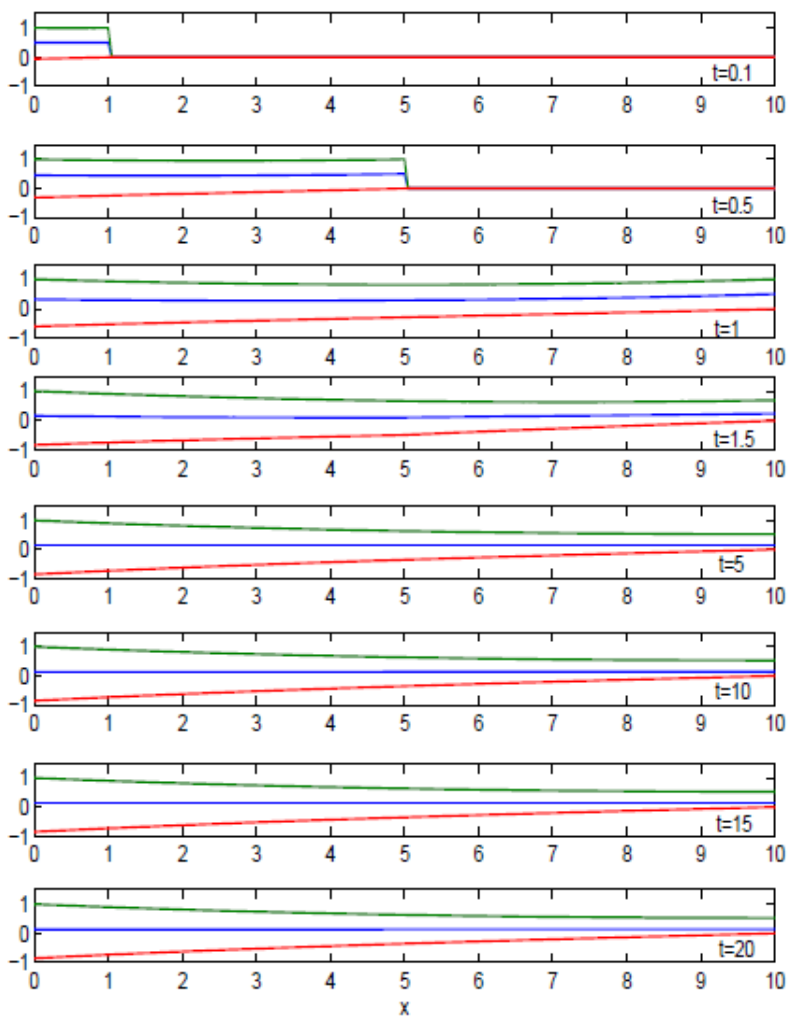

Gambar 4 Grafik $A(x, t)$ : hijau, $B(x, t)$ : merah, dan fluks energi: biru, untuk $A_{0}=1, L=10, B(10, t)=0, \varepsilon G=0.08$

\section{Kasus 2 Muara Sungai Memantulkan Gelombang dengan $B(L, t)=-A(L, t)$}

Bendungan di muara sungai yang memiliki mempengaruhi perambatan gelombang yang melalui dinding sinusoidal. Hal ini dapat dilihat pada Gambar 5. Penjelasan serupa dengan kasus 1 untuk $t \leq 1$. Bandingkan Gambar 4 dengan Gambar 5. Perbedaan yang signifikan dapat dilihat pada saat $\mathrm{t}=1.5$. Hal ini disebabkan karena pada kasus 1 , gelombang transmisi terserap sempurna di sebelah kanan, sedangkan pada Gambar 5, gelombang transmisi sudah mencapai bendungan dan dipantulkan sempurna oleh bendungan tersebut sehingga amplitudo gelombang refleksi tidak hanya dipengaruhi oleh dinding sinusoidal, tetapi juga dipengaruhi oleh bendungan yang memantulkan gelombang secara sempurna dengan pembalikkan fase sebesar $\pi$. Pada saat $t=1.5$, pengaruh adanya pantai baru dirasakan oleh gelombang refleksi yang berada di daerah $\mathrm{x}>5$ dan pengaruh ini menyebabkan gelombang refleksi memiliki beda fase sebesar $\pi$. Sedangkan di daerah lainnya belum terjadi pembalikkan fase. Pada kasus ini, transfer energi terjadi dalam waktu yang lebih lama dibandingkan dengan Kasus 1. Pada saat $\mathrm{t}=10$, sudah tidak ada lagi transfer energi. Pada akhirnya diperoleh bahwa amplitudo gelombang datang terreduksi hingga $\pm 30 \%$ untuk $\varepsilon G=0.08$. 

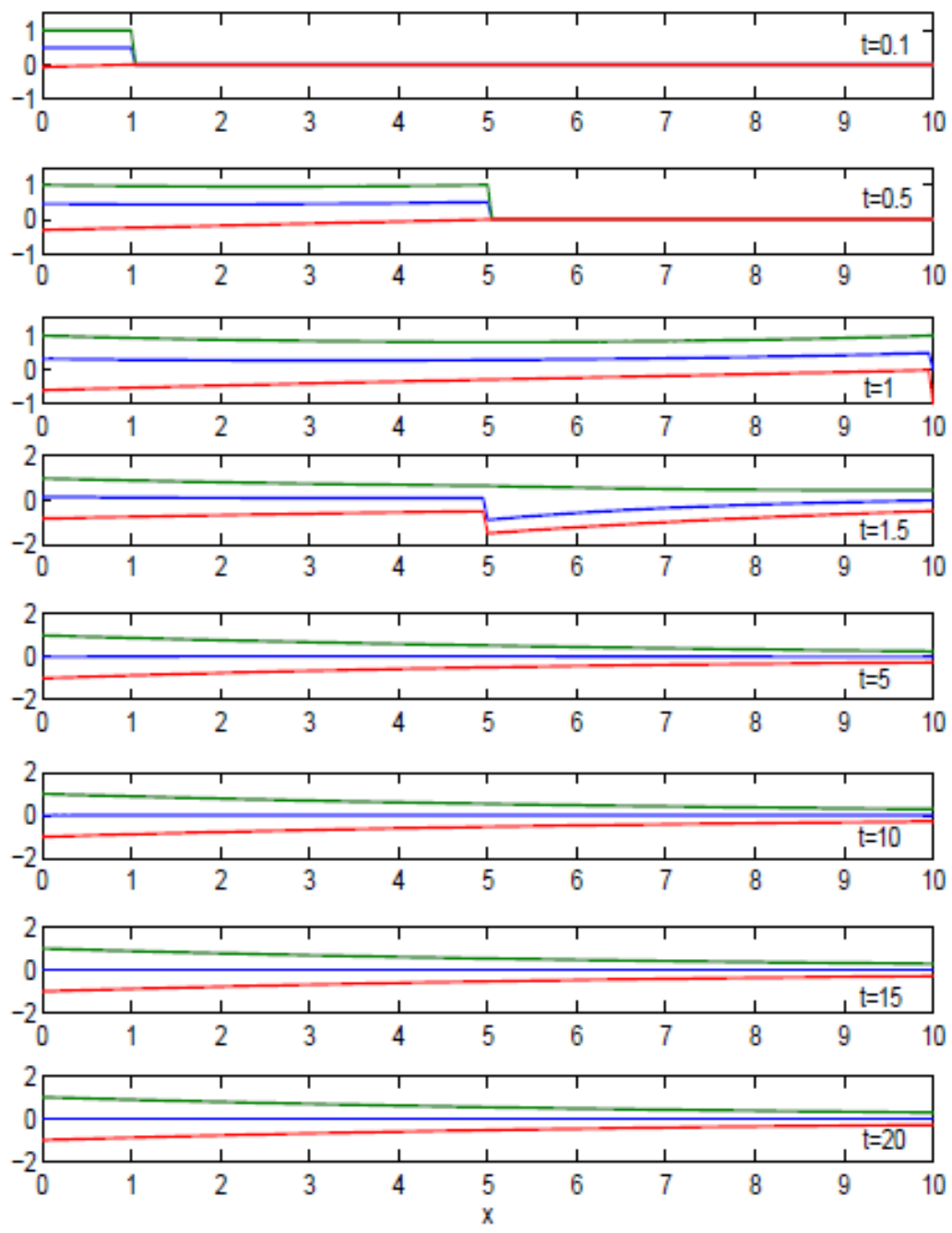

Gambar 5 Grafik $A(x, t)$ : hijau, $B(x, t)$ : merah, dan fluks energi: biru, untuk $A_{0}=1, L=10$, $B(10, t)=-A(10, t), \varepsilon G=0.08$.

\section{Kasus 3 Muara Sungai Memantulkan Gelombang dengan $B(L, t)=A(L, t)$}

Perambatan gelombang yang melalui dinding sinusoidal dan berada di sekitar bendungan yang berkarakteristik $B(L, t)=A(L, t)$ dapat dilihat pada Gambar 6 . Untuk $t \leq 1$, penjelasan yang serupa dengan kedua kasus sebelumnya berlaku juga pada kasus ini. Pada saat $t=1.5$, efek adanya muara sungai baru terasa di sebagian daerah, yaitu pada $x>5$. Pada daerah ini, amplitudo gelombang refleksi sama dengan amplitudo gelombang transmisi karena muara sungai memantulkan gelombang secara sempurna tanpa ada pembalikkan fase. Pada saat $t=10$, efek muara yang berupa bendungan sudah dirasakan di sepanjang daerah dinding sinusoidal sehingga hampir di setiap $x$ amplitudo gelombang refleksi bernilai hampir sama dengan amplitudo gelombang transmisi.

Transfer energi antara $A$ dan $B$ sudah tidak ada lagi setelah $t=10$ sehingga nilai $A$ dan $B$ sudah tidak berubah-ubah terhadap posisi. Transfer energi membutuhkan waktu yang lebih lama daripada kedua kasus sebelumnya. Pada akhirnya diperoleh bahwa amplitudo gelombang dating sama sekali tidak tereduksi. Bahkan gelombang transmisi yang menuju bendungan memiliki 
amplitudo sekitar empat kali lipat amplitudo gelombang datang untuk $\varepsilon E=0.08$ karena pada kasus ini akan terjadi superposisi konstruktif. Jelas ini sangat membahayakan kehidupan warga yang tinggal di sekitar bendungan karena mungkin saja tinggi dinding bendungan tersebut lebih rendah daripada amplitudo yang menerjang bendungan sehingga air sungai keluar dari bendungan dan bisa mengakibatkan banjir.
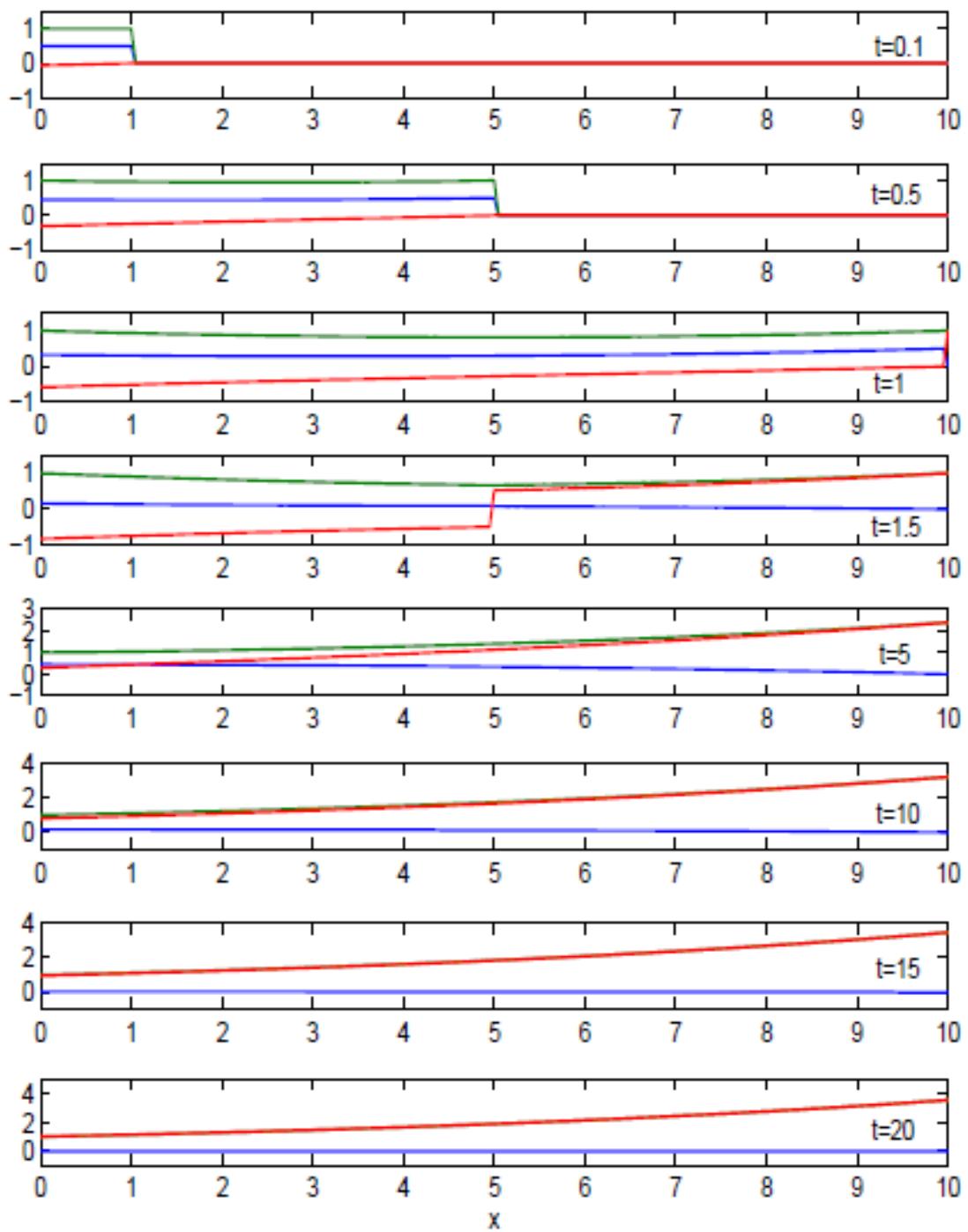

Gambar 6 Grafik $A(x, t)$ : hijau, $B(x, t)$ : merah, dan fluks energi: biru, untuk $A_{0}=1, L=10$, $B(10, t)=A(10, t), \varepsilon G=0.08$.

\section{SIMPULAN}

Dinding sungai sinusoidal yang memiliki bilangan gelombang sebesar dua kali lipat bilangan gelombang yang datang akan menyebabkan terjadinya resonansi Bragg. Besarnya amplitudo gelombang transmisi dan gelombang refleksi yang dihasilkan sangat dipengaruhi oleh besarnya amplitudo dinding sinusoidal dan karakteristik muara sungai (dalam hal ini bendungan) dalam menyerap atau memantulkan gelombang. Keberadaan dinding sinusoidal dapat mereduksi 
amplitudo gelombang yang menabrak bendungan dengan cukup signifikan dalam kasus bendungan bersifat menyerap gelombang secara sempurna atau memantulkan secara sempurna disertai dengan pembalikan fase sebesar $\pi$. Dalam kasus bendungan hard wall atau bersifat memantulkan gelombang tanpa pembalikkan fase, akan terjadi superposisi konstruktif antar gelombang-gelombang yang menabrak bendungan. Dalam kasus ini, keberadaan dinding sinusoidal akan memperbesar amplitudo gelombang yang menabrak bendungan hingga lebih dari dua kali lipat. Kajian tiga jenis bendungan dengan sifat ekstrim yang berbeda-beda di atas dapat memberikan gambaran mengenai pengaruh dinding sinusoidal sebagai penahan gelombang.

\section{DAFTAR PUSTAKA}

Hirose, A., and Karl. E. L. (1985). Introduction to wave phenomena, New York: John Wiley and Sons.

Holmes, M. H. (1995). Introduction to perturbation methods, New York: Springer-Verlag.

Mei, C. C. (2004). Multiple scattering by an extended region of inhomogeneities. Wave Propagation, Fall.

Noviantri, V. (2007). Dasar laut dan dinding sinusoidal sebagai reflektor gelombang. Tugas Akhir S1, Institut Teknologi Bandung.

Philip, L., and Liu, F. (1986). Resonant reflection of water waves in a long channel with corrugated boundaries. J.Fluid Mech, 179, 371-381, New York: Cornell University.

Strauss, A. W. (1992). Partial differential equations an introduction, New York: John Wiley and Sons.

Yu, J., and Mei, C. C. (2000). Do longshore bars shelter the shore?. J.Fluid Mech, 404, 251-268, United States of America: Cambridge University. 